\title{
ICE-WEDGE ICE, MACKENZIE DELTA-TUKTOYAKTUK PENINSULA AREA, N.W.T., GANADA
}

\author{
By W. Alan Gell \\ (R. M. Hardy \& Associates Ltd., $3102055^{\text {th }}$ Avenue S.W., Calgary, Alberta T2E 6J5, \\ Canada)
}

\begin{abstract}
Petrologic analysis was performed on ice-wedge ice in order to investigate changes in fabric across wedges in relation to the growth mechanism. Crystal size increased from the centre outward and strongly preferred dimensional orientations developed parallel to the sides of wedges. $c$-axis orientations changed from a horizontal girdle at the wedge centre to a point maximum normal to the foliation at the boundary. These changes are related to recrystallization and grain growth associated with the horizontal stress field. In massive ice penetrated by an ice wedge, crystal size and complexity of crystal shape decreased toward the wedge, dimensional orientations tended to become parallel to the wedge, and $c$-axes formed a
point maximum normal to the wedge boundary.
\end{abstract}

RÉsumé. Glace des "coins de glace" dans le delta du Mackenzie, zone de la péninsule Tuktoyaktuk, N.W.T., Canada. On a conduit une analyse pétrologique sur la glace des "coins de glace" en vue de déterminer les changements dans les orientations des axes dans les coins en relation avec le mécanisme de la croissance. La taille des cristaux grandit du centre vers l'extérieur et la dimension parallèle aux côtés du coin est très largement favorisée. Les orientations des axes- $c$ changent depuis une disposition en cristaux horizontale au centre du coin jusqu'à un point maximum normal à la foliation vers les bords. Ces changements sont liés à la massive traversée par la croissance des grains associés au champ des forces horizontales. Dans une glace massive traversée par un coin de glace, la taille des cristaux et la complexité des formes cristallines diminuent en allant vers le coin, les grandes dimensions des cristaux tendent à devenir parallèles au coin et les axes-c présentent une orientation préférentielle normale à la paroi du coin.

Zusammenfassung. Eiskeile im Mackenzie Delta und im Gebiet der Tuktoyaktuk Peninsula, N.W.T., Kanada. Eis aus Eiskeilen wurde petrologisch untersucht, um Gefügeänderungen innerhalb der Keile in Abhängigkeit vom Wachstumsablauf festzustellen. Die Grösse der Kristalle nahm von innen nach aussen zu; ihre räumliche Orientierung richtete sich bevorzugt parallel zu den Seiten des Keiles. Die Orientierung der $c$-Achsen ging von einem horizontalen Gürtel im Keil-Zentrum zu einer Stellung senkrecht zur Bänderung am Rande über. Dieser Wechsel hängt mit der Rekristallisation und dem Kornwachstum zusammen, die mit dem horizontalen Spannungsfeld verbunden sind. In massivem Eis, das von einem Eiskeil durchdrungen wird, nahm die Korngrösse und die Kompliziertheit der Kristallformen gegen den Keil hin ab, die räumliche Orientierung strebte nach Parallelität mit dem Keil und die $c$-Achsen erreichten eine Häufung senkrecht zum Keilrand.

\section{INTRODUGTION}

Ice wedges and associated polygons are common features in the continuous permafrost zone. Leffingwell ( 1915 ) proposed the thermal contraction theory of wedge growth, which gained theoretical support from Lachenbruch (1962). According to this theory, cracking results from constrained thermal contraction produced by rapid surface-temperature drops superimposed on generally low temperatures. Such cracks may be infilled by hoar frost, snow and surface water, although some closure of the cracks may also occur by compression of the ground prior to operation of infill processes. Repetition of this mechanism eventually produces an ice wedge. Wedges are abundant in the Tuktoyaktuk Peninsula-Mackenzie Delta area, where Mackay (I974) has recorded cracking patterns and associated ground temperatures. It is the intention in this paper to discuss petrological aspects of wedge ice in terms of: (I) crystal and inclusion variations across a wedge, and (2) the influence of a growing wedge on the fabric of massive ice penetrated by the wedge.

\section{FIELd AND LABORATORY TEGHNiQUES}

Ice samples were obtained with a CRREL corer and, on accessible coastal exposures, with a chain saw. Samples were transported in freezer boxes by helicopter to cold storage at $<-20^{\circ} \mathrm{C}$. Thin sections were prepared by microtome (for details see Langway (1958)) and standard universal-stage techniques were employed. 
THE FABRIC OF IGE-WEDGE ICE

\section{Field characteristics}

Samples of ice-wedge ice were collected from the north-west coast of Pelly Island (Fig. I) in a low-lying area of polygon flats in lacustrine clays. Wedges were exposed in section on a low cliff subject to coastal recession (Fig. 2). Many wedges were 2-3 $\mathrm{m}$ across at their upper surfaces and had been subject to thermokarst modification. In 1974, two large wedges were sampled in order to investigate variations in texture and fabrics across the wedges.

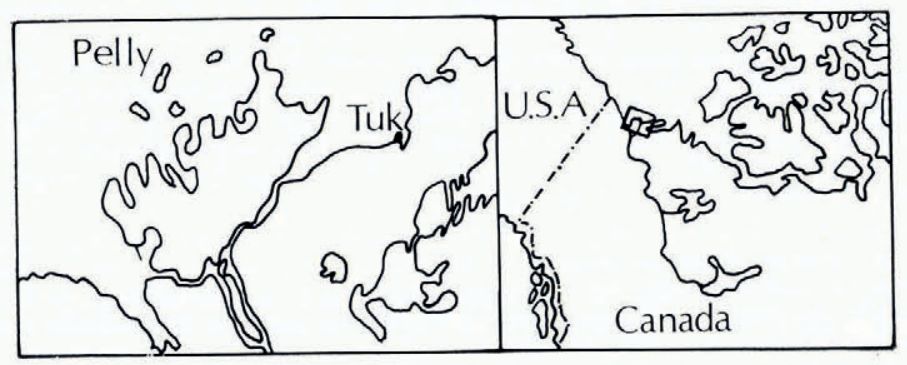

Fig. I. Location map.

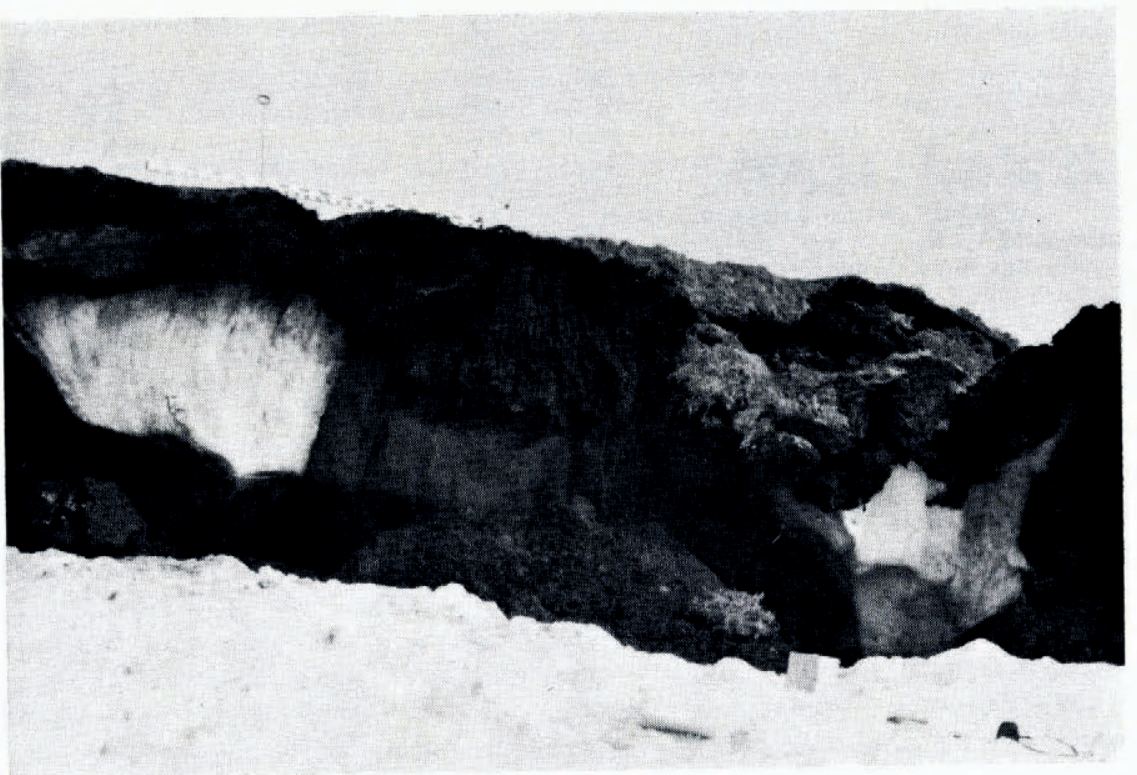

Fig. 2. Ice wedges in cliff, Pelly Island.

\section{Inclusion characteristics}

Wedge ice has a foliation (Fig. 3) produced by repetitive infilling of vertical cracks which form near the wedge centre. Through time these develop a characteristic fan-shaped foliation which is recognizable by bubble and sediment content. In the Pelly Island wedges the youngest fractures at wedge centres generally contain large sub-planar inclusions of peat and sediment. The older the inclusion, the more it has become disintegrated and offset by later fractures. Vertical bubble bands at the wedge centres are generally $2-3 \mathrm{~mm}$ wide and contain 
bubbles up to $8 \mathrm{~mm}$ long. Considerable variation in bubble concentration is evident within individual bands. At wedge boundaries, bands are up to $20 \mathrm{~mm}$ wide and contain vertically elongate bubbles which range to io $\mathrm{mm}$ long.

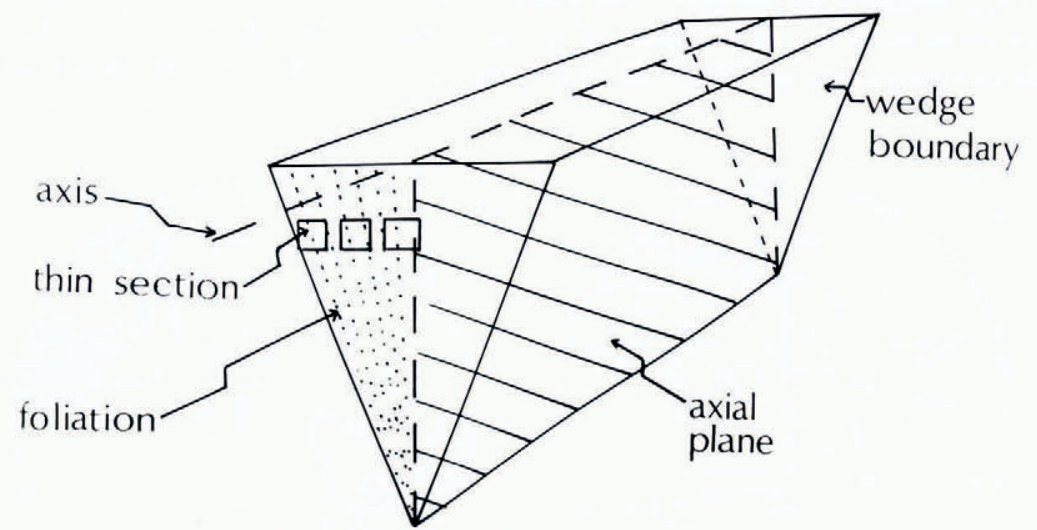

Fig. 3. Components of ice wedge and thin-section orientations.

\section{Crystal characteristics}

Thin sections of several orientations were prepared but it was found that maximum information was obtained from vertical thin sections normal to the wedge axis (Fig. 3).

Average crystal size, in vertical thin sections normal to the wedge axis, varies from $12 \mathrm{~mm}^{2}$ at the wedge centre to $>30 \mathrm{~mm}^{2}$ at the wedge boundary. The preferred dimensional orientation of new crystals, in the younger central cracks, is approximately normal to the crack wall, i.e. usually horizontal. A vertical preferred orientation develops rapidly away from the central cracks, and at wedge boundaries is highly preferred parallel to the boundaries. Larger polygonal crystals near wedge centres are embayed where small grains have grown. The fabric throughout the wedge is disrupted by fractures but cracking is more frequent near the wedge centre. This is evident petrographically in wedges on Pelly Island and elsewhere in the Mackenzie Delta area (Gell, unpublished), and Mackay (r974) has demonstrated central cracking in wedges on Garry Island by measurement and by re-location, in successive years, of markers inserted into open cracks in winter.

Fabric diagrams for ice from the wedge centre and boundary are presented in Figure 4 . $c$-axes in central ice form a broad sub-horizontal girdle (Fig. 4a) with local concentrations associated with recent fractures. The fabric changes from wedge centres to boundaries; at the boundaries it displays a strong point concentration normal to the foliation (Fig. 4b) and a minor girdle normal to the foliation. The overall fabric is thus re-orientated into a higher symmetry than that of the centre of the wedge. Component diagrams based on crystal size show that crystals $<$ Io $\mathrm{mm}^{2}$ tend toward a girdle pattern, which was characteristic of the wedge centre, while the larger the crystals, the closer the approximation to a point concentration (Fig. 4c-e). The small crystals represent a recent crack infill.

\section{DisGussion OF WEDGE ICE}

Black ([ ${ }^{c}$ I974], unpublished) studied fabrics in active and buried wedges in Alaska, and defined seven types of $c$-axis distribution, of which the three most widespread were: (I) vertical, (2) normal to the wedge axis and horizontal, and (3) normal to the wedge axis and inclined. Growth fabrics were ascribed to orientation of nuclei, directional feeding, directional heat conduction, and interference of other grains. Superimposed on these fabrics were deformation 
fabrics; horizontal and inclined $c$-axes were attributed to crystals responding to shear stress. Vertical dimensional orientation of crystals was attributed by Black to recrystallization under strong temperature gradients and inclined long axes were related to inclined thermal gradients. Shumskiy (r955) studied ice wedges ("perennial vein ice") in the U.S.S.R. and found $c$-axis maxima to be vertical in the upper parts of wedges, and horizontal, normal to the axial planes of wedges, in the lower parts. These were termed "primary texture" by Shumskiy.
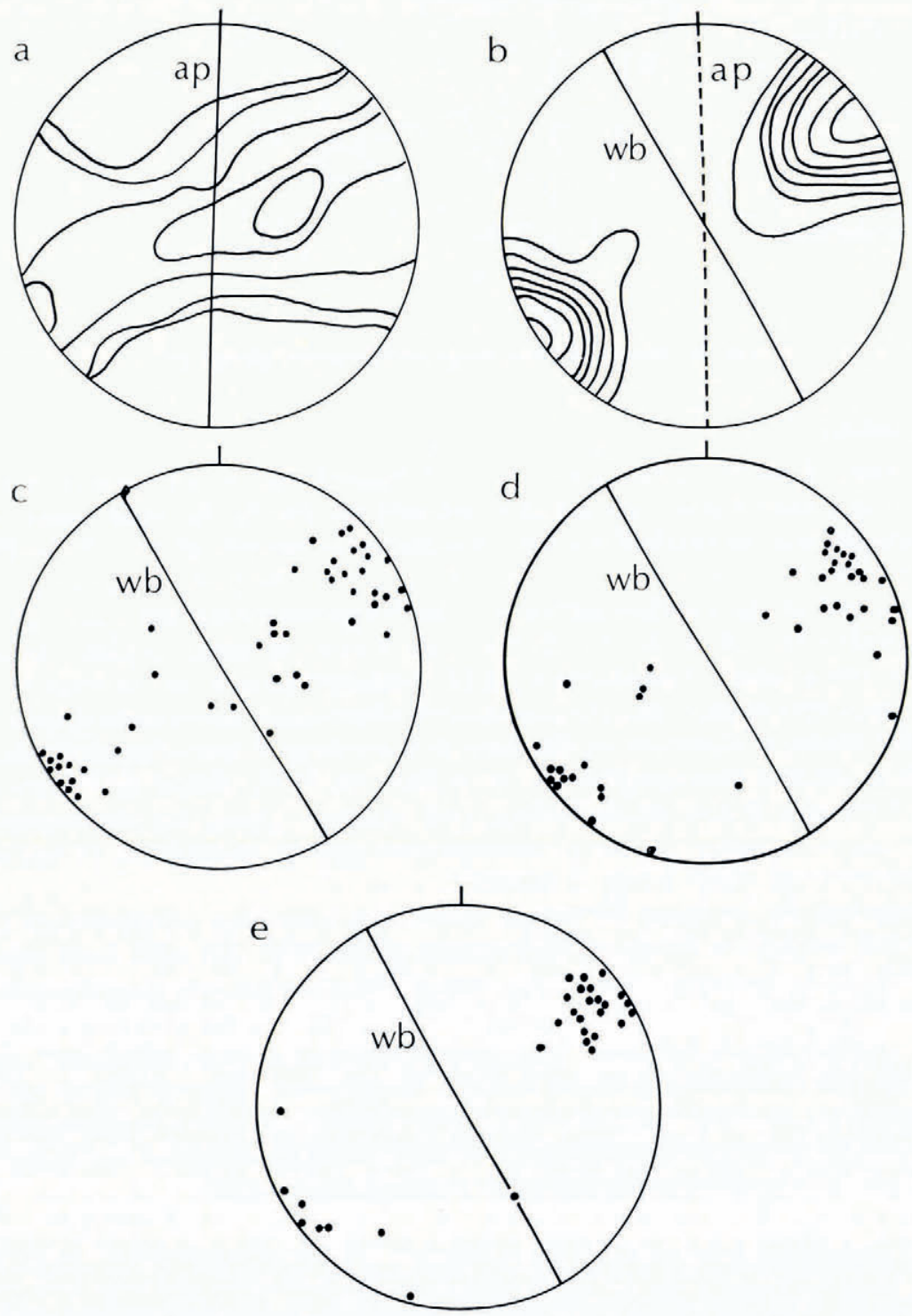

Fig. 4. Fabric diagrams of ice-wedge ice. Diagrams in vertical plane, normal to wedge axis.

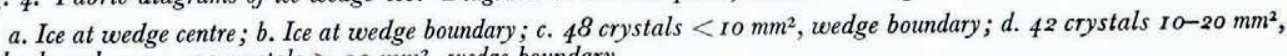
wedge boundary; $e .30$ crystals $>20 \mathrm{~mm}^{2}$, wedge boundary.

ap, axial plane of wedge; wb, wedge boundary.

Contours at intervals of $2,4,6,8,10$ and $I 2 \sigma$, by the method of Kamb (I959). 
The large wedges studied here have similar fabrics in corresponding wedge segments and correlate with some of those recorded by Black ( $\left[{ }^{\mathrm{C}} \mathrm{I} 974\right]$, unpublished) and by Shumskiy (1955). The systematic changes in crystal characteristics with distance from the wedge centre are indicative of recrystallization and grain growth. Recrystallization has produced a strong $c$-axis preferred orientation such that basal planes are parallel to foliation and wedge boundaries, and are favourably orientated for intracrystalline plastic flow (Fig. 3). Black ([ $\left.{ }^{{ }}{ }_{1974}\right]$, unpublished) suggested that shear planes occur adjacent and parallel to wedge sides. This is supported by the Pelly Island observations of oblique-crack infills and sediment inclusions which have been offset by several millimetres parallel to the wedge boundary. Black ([ ${ }^{\mathrm{C}}{ }_{1974}$ ) considered that some small rectangular crystals resulted from "rapid shear at low temperatures". However, $c$-axis distributions of small crystals near the boundaries of wedges on Pelly Island were found to be similar to those of recent central cracks (Fig. 4c). Grain growth is demonstrated by the larger size of the majority of crystals at wedge boundaries, compared with more recently grown ice in cracks both at wedge centres and, more rarely, near wedge boundaries. Grain coarsening during deformation is well documented (Steinemann, I956; Kamb, I972). This coarsening is expected to aid the creep process, as the large grains are favourably orientated for flow. In the experiments of Kamb (1972), it was found that textures had reached an essentially steady state in a few days. Also, a slight elongation parallel to the shear plane was reported by Kamb (1972) which corresponds with the dimensional orientations of marginal crystals in wedges on Pelly Island, and some in Alaska (Black, $\left[{ }^{\mathrm{C}}{ }_{1974]}\right.$ ). The influence of temperature gradients on crystal dimensional orientation as suggested by Black $\left(\left[{ }^{{ }^{1}}{ }_{1974]}\right)\right.$ has not been studied experimentally. Bubbles in the outer wedge ice are vertically elongate. It is known that bubbles in ice migrate along temperature gradients (Stehle, 1967; Kheysin and Cherepanov, r969) and this may be expected to occur in ice wedges (Black, $\left[{ }^{\mathrm{c}}{ }_{\mathrm{I}} 974\right]$ ). But elongation, flattening, and migration of bubbles may also result from the imposed stress system (Kamb, 1972). During grain growth it is likely that impurities are concentrated on grain boundaries, although larger inclusions such as elongate bubbles may transect boundaries. Impurity concentration tends to weaken boundaries and to increase cracking susceptibility.

\section{The influence of Wedge growth on adjagent massive ice}

In addition to sites, such as Pelly Island, where wedge systems have developed in sediments and organic matter, wedges also grow within segregated ice bodies (Fig. 5). This latter type is less frequent and is characterized by development of larger polygons. As an example, a site on an ice-cored hill near Tuktoyaktuk was selected for study. Recent cracks were identified petrographically, thus the wedge which was studied appeared to be growing, and thus actively stressing the surrounding ice. The compositional layering of the massive ice is deformed adjacent to the wedge and a series of offsets has developed parallel to its margin.

\section{Crystal characteristics}

Crystal size in the segregated ice decreases toward the wedge boundary (Fig. 5). This is attributed to the polygonization of larger grains and the growth of new grains orientated favourably to accommodate the stress exerted during summer expansion. A similar variation in crystal size in massive ice penetrated by a wedge was found by Corte (1962) in Greenland. Crystal shape in the segregated ice also changes with distance from the wedge. Inequigranular interlocking crystals occur at a distance of $5 \mathrm{~m}$ from the wedge, which is typical of the massive ice. Adjacent to the wedge, crystal boundaries in small polygonal crystals are straight or gently curved. Also, the fabric pattern (Fig. 5) changes from a $c$-axis maximum, normal to the compositional layering of the segregated ice at $5 \mathrm{~m}$ from the wedge, which is 

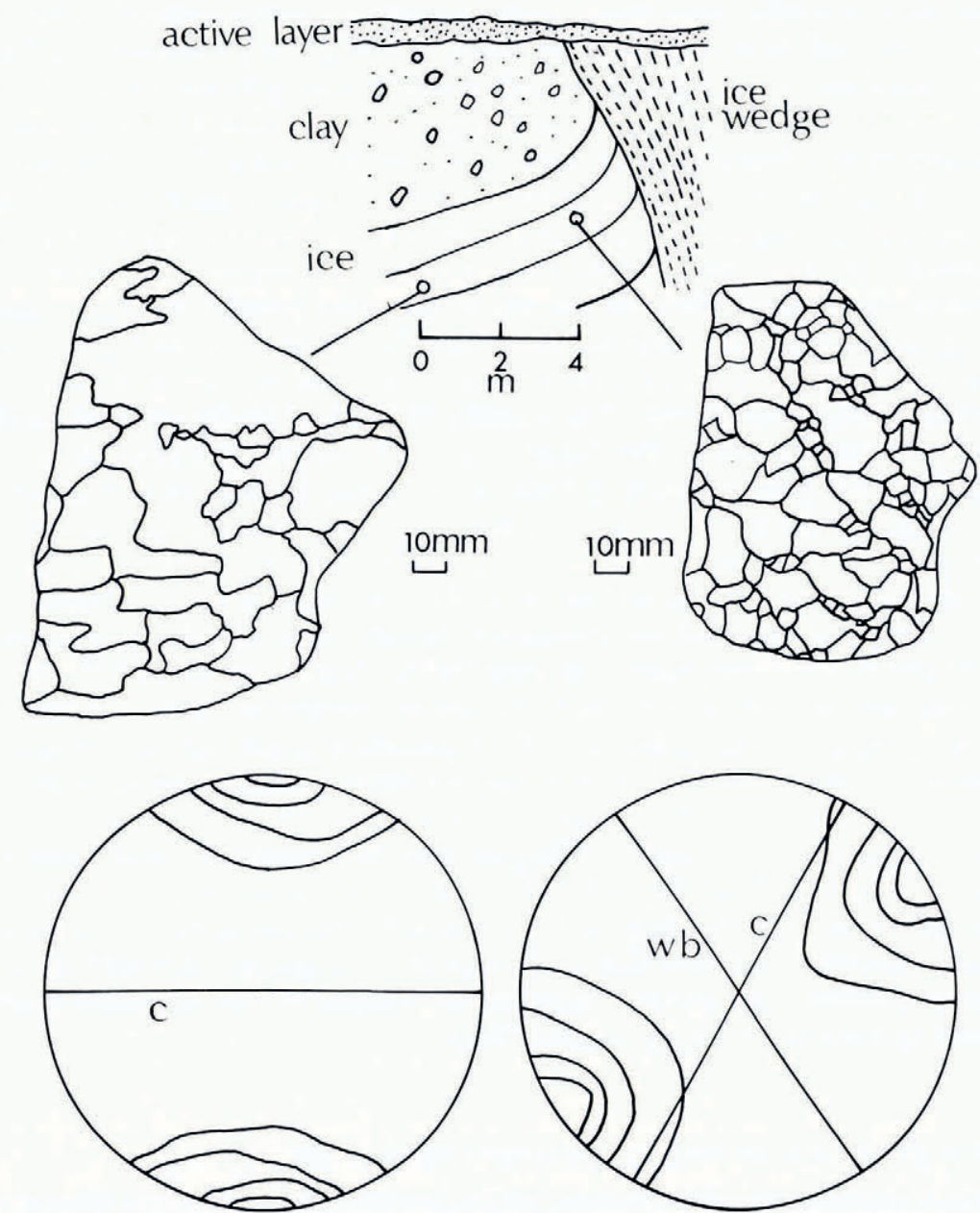

Fig. 5. Crystal characteristics, massive ice penetrated by ice wedge, Tuktoyaktuk Peninsula.

Fabric diagrams: Ioo crystals, contours at intervals of 2, 4, 6 and $8 \sigma$, by the method of Kamb (1959). $c$, compositional layering of massive ice; wb, wedge boundary.

characteristic of massive ice, to a maximum close to the layering, and normal to the wedge boundary, adjacent to the wedge, which is typical of wedge ice. Thus, while the compositional layering of the segregated ice is folded adjacent to the wedge, the contained crystals near the wedge respond to the stress system in a manner similar to that of the outer wedge crystals. The marked change in lattice orientation indicates that recrystallization has occurred. Also, crystal dimensional orientations show a maximum parallel to the compositional layering $5 \mathrm{~m}$ away from the wedge and a maximum parallel to the wedge in segregated ice at the contact with the wedge.

\section{DisGuSSION OF INFLUENGE OF WEDGE ON MASSIVE IGE}

Progressive changes in textural and fabric characteristics with distance from the wedge result from compression caused by summer expansion of permafrost. Stress is at a maximum adjacent to the wedge and decreases with distance from the wedge. The only previous similar 
reference to the influence of a wedge is by Corte ( 1962$)$, who found that changes in fabric in the surrounding ice, were confined to a distance of $30 \mathrm{~cm}$ from a small ( $\mathrm{I} \mathrm{m}$ wide) wedge. In the present study, modification of fabric was recorded up to $4 \mathrm{~m}$ from a large ( $3 \mathrm{~m}$ wide) wedge. Although the undisturbed segregated ice and central wedge ice are markedly different in texture and fabric, the fabrics at the contact of the two ices are similar. These fabrics result from the stress system associated with the growing wedge. In addition to shear within wedges, offsets approximately parallel to the wedge boundary were observed in the segregated ice. By matching crystals on each side, it was apparent that movement of $6 \mathrm{~mm}$ had occurred.

\section{Conclusions}

Systematic changes were observed in crystal size, shape, and lattice and dimensional orientation across large ice wedges and were correlated with the wedge-growth process. Crystal size increased from the centre outwards and a point-maximum fabric pattern developed normal to the wedge boundary, and a dimensional orientation parallel to the wedge boundary. These changes result from recrystallization and grain growth. Where a large wedge penetrated massive segregated ice, a progressive change in petrologic features, related symmetrically to the wedge, was identified in the massive ice. Crystal size and complexity of crystal shape decreased toward the wedge and the fabric maximum was rotated to become normal to the wedge. Dimensional orientation became parallel to the wedge, due to the imposed stress.

\section{Acknowledgements}

Field work was supported by the Geological Survey of Canada, the Polar Continental Shelf Project (Department of Energy, Mines and Resources, Canada) and Inuvik Research Laboratory, and grants to Dr J. R. Mackay from the National Research Council of Canada, and the Department of Indian Affairs and Northern Development, Canada. J. R. Mackay gave helpful comments on the manuscript.

MS. received 28 March 1977

\section{REFERENCES}

Black, R. F. [ [ ${ }^{\mathrm{c}}$ 1974.] Ice-wedge polygons of northern Alaska. (In Coates, D. R., ed. Glacial geomorphology. .. 1974. Binghamton, N.Y., State University of New York, p. 247-75. (Publications in Geomorphology.))

Black, R. F. Unpublished. Fabrics of ice wedges. [Ph.D. thesis, Johns Hopkins University, Baltimore, I953.]

Corte, A. E. 1962. Relationship between four ground patterns, structure of the active layer and type and distribution of ice in the permafrost. U.S. Cold Regions Research and Engineering Laboratory. Research Report 88.

Gell, W. A. Unpublished. Underground ice in permafrost, Mackenzie Delta-Tuktoyaktuk Peninsula, N.W.T. [Ph.D. thesis, University of British Columbia, Vancouver, I 976.]

Kamb, W. B. I959. Ice petrofabric observations from Blue Glacier, Washington, in relation to theory and experiment. Journal of Geophysical Research, Vol. 64, No. i 1, p. 1891-19o9.

Kamb, W. B. 1972. Experimental recrystallization of ice under stress. (In Heard, H. C., and others, ed. Flow and fracture of rocks, edited by H. D. Heard, I. Y. Borg, N. L. Carter and C. B. Raleigh. Washington, D.C., American Geophysical Union, p. 21 I-4I. (Geophysical Monograph I6.))

Kheysin, D. Ye., and Cherepanov, N. V. r969. Preobrazovaniye formy i peremeshcheniye vozdushnykh vklyucheniy vo l'du [Transformation and movement of air inclusions in ice]. Problemy Arktiki $i$ Antarktiki, Vyp. 32, p. $100-05$.

Lachenbruch, A. H. 1962. Mechanics of thermal contraction cracks and ice-wedge polygons in permafrost. Geological Society of America. Special Paper 70.

Langway, C. C., jr. 1958. Ice fabrics and the universal stage. U.S. Cold Regions Research and Engineering Laboratory. Technical Report 62.

Leffingwell, E. de K. I915. Ground-ice wedges; the dominant form of ground-ice on the north coast of Alaska. Journal of Geology, Vol. 23, No. 7, p. 635-54.

Mackay, J. R. 1974. Ice-wedge cracks, Garry Island, Northwest Territories. Canadian Journal of Earth Sciences, Vol. i i, No. io, p. 1366-83. 
Shumskiy, P. A. 1955. Osnovy strukturnogo ledovedeniya: petrografiya presnogo l'da kak metod glyatsiologicheskogo issledovaniya. Moscow, Izdatel'stvo Akademii Nauk SSSR. [English translation: Principles of structural glaciology: the petrography of fresh-water ice as a method of glaciological investigation. Translated from the Russian by David Kraus. New York, Dover Publications, 1964.]

Stehle, N. S. 1967 . Migration of bubbles in ice under a temperature gradient. (In Oura, H., ed. Physics of snow and ice: international conference on low temperature science. . . 1966. . . . Proceedings, Vol. I, Pt. I. [Sapporo], Institute of Low Temperature Science, Hokkaido University, p. 219-32.)

Steinemann, S. I956. Flow and recrystallization of ice. Union Géodésique et Géophysique Internationale. Association Internationale d'Hydrologie Scientifique. Assemblée générale de Rome 1954, Tom. 4, p. 449-62. (Publication No. 39 de l'Association Internationale d'Hydrologie.) 